\title{
LEMBAGA PENDIDIKAN DASAR DALAM SEJARAH ISLAM PERIODE KLASIK
}

\author{
Fathurrahman \\ Institut Agama Islam (IAI) Muhammadiyah Bima \\ Email: fathunkbima@gmail.com
}

\begin{abstract}
Abstrak
Peninggalan masyarakat Arab pra Islam ini yang berkaitan dengan proses transformasi pengetahuan kemudian diadopsi oleh masyarakat Islam sebagai bentuk awal pendidikan bagi anakanak Muslim pada masa itu. Melalui lembaga inilah internalisasi nilai-nilai Islam ditanamkan disamping pembelajaran lainnya yang berkaitan dengan pendidikan jasmaniyah. Dalam perkembangannya, setelah Islam semakin meluas, perkembangan lembaga pendidikan dalam Islam pun semakin berkembang dari tingkat pendidikan dasar hingga pendidikan tinggi yang berlangsung secara terstruktur dan sistematis mulai menemukan bentuknya. Sejak 750-1350 M pendidikan dasar di kalangan umat Islam hampir terdapat dimana-mana di seluruh kawasan Islam. Para khalifah Abbasiyah adalah pendukung pendidikan dan pelajaran baca tulis. Dimulai sejak Harun al-Rasyid, mereka berpendapat bahwa setiap anak-anak Muslim memiliki kesempatan untuk belajar dasar-dasar membaca, menulis, berhitung, ilmu pengetahuan dasar, geografi, sejarah dan sebagainya. Proses pelaksanaan penddikan dasar Islam pun dilakukan dilingkuan pendidkan keluarga, Masjid, Kuttab, teramasuk dalam sekolah istana, sebagai upaya pengembangan pendidikan Islam sedari dini dalam diri seorang muslim dalam bingkai ajaran agama Islam.
\end{abstract}

Kata Kunci: Sejarah, Pendidikan Dasar, Islam

\section{PENDAHULUAN}

Donggak sejarah pendidikan dalam Islam mulai berlangsung sejak diangkatnya Muhammad Saw menjadi Nabi dan Rasul oleh

L Allah Swt yang ditandai dengan diterimanya wahyu pertama melalui malaikat Jibril di gua Hira pada tahun $610 \mathrm{M}$ yang berisi tentang perintah untuk membaca. Perintah ini kemudian disusul oleh wahyu kedua yang berisi perintah kepada Nabi untuk bangkit memberikan peringatan kepada manusia dan membesarkan nama Allah, meninggalkan kebiasaan-kebiasaan buruk seperti menyembah berhala, 
agar hidup bersih lahir dan batin. Dengan turunnya wahyu yang pertama dan kedua ini, mulailah gerakan pendidikan dan pengajaran di dalam Islam pertama di Makkah. Pada masa awal perkembangan Islam, pendidikan Islam formal yang sistematis belum terselenggara. Pendidikan yang berlangsung dapat dikatakan umumnya bersifat informal, dan inipun lebih berkaitan dengan upaya-upaya dakwah islamiyah - penyebaran, penanaman dasar-dasar kepercayaan dan ibadah Islam. Hal ini disebabkan masyarakat Arab Arab pra Islam pada dasarnya tidak mempunyai sistem pendidikan formal (Armai Arif, 2004).

Meskipun tidak memiliki sistem pendidikan formal, sebagian masyarakat Arab pada waktu itu sebenarnya telah memiliki tingkat budaya literasi yang cukup tinggi, walaupun daerah mereka tampak terisolisasi dari dunia luar, tidak sedikit dari mereka, terutama kaum pedagang, yang telah mengalami kontak dengan budaya dan peradaban dunia luar, karena pada hakekatnya daerah Hedjaz/ Hijaz merupakan jalan dagang yang strategis menghubungkan Syam di utara dan Yaman di selatan. Maka, terciptalah transformasi budaya di kalangan mereka sehingga banyak di antara mereka yang pandai baca tulis. Hal ini terbukti ketika banyak tawanan yang pandai baca tulis, Nabi Muhammad SAW menyetujui pembebasan tawanan itu dengan mengajarkan baca tulis kepada sepuluh anak muslim (Syafiq, 2002: 19).

Hanya saja, perkembangan pendidikan masyarakat Arab pra Islam saat itu tidak berkembang pesat dan melahirkan peradaban besar sebagaimana yang telah dilakukan oleh umat Islam. Hal yang demikian dapat dimaklumi mengingat pada saat itu sebagian penduduk di Jazirah Arab adalah penduduk yang memiliki kebiasaan hidup berpindah-pindah (nomaden). Tentu perhatian yang mereka berikan lebih besar pada pemenuhan kebutuhan-kebutuhan primer berupa makanan, sementara kegiatan pendidikan menjadi kebutuhan yang sekunder atau bahkan mereka anggap tidak penting sama sekali. Karena keterampilan membaca dan menulis belum menjadi hal yang umum dimiliki masyarakat, maka yang berkembang dalam proses transformasi nilainilai kepada generapa muda adalah tradisi lisan. Dalam kondisi seperti itu, yang menjadi 'guru' adalah mereka yang paling banyak memiliki 
hafalan (Charles Michael, 1994: 14). Karena mereka inilah yang menceritakan seluk beluk kehidupan suku mereka di padang pasir dengan semua tradisi yang dimilikinya.

Peninggalan kecil masyarakat Arab pra Islam ini yang berkaitan dengan proses transformasi pengetahuan ini yang kemudian diadopsi oleh masyarakat Islam sebagai bentuk awal pendidikan bagi anak-anak Muslim pada masa itu. Melalui lembaga inilah internalisasi nilai-nilai Islam ditanamkan disamping pembelajaran lainnya yang berkaitan dengan pendidikan jasmaniyah. Dalam perkembangannya, setelah Islam semakin meluas, perkembangan lembaga pendidikan dalam Islam pun semakin berkembang dari tingkat pendidikan dasar hingga pendidikan tinggi yang berlangsung secara terstruktur dan sistematis mulai menemukan bentuknya. Mehdi Nakosteen menyebutkan sejak 750-1350 $\mathrm{M}$ pendidikan dasar di kalangan umat Islam hampir terdapat dimanamana di seluruh kawasan Islam. Para khalifah Abbasiyah adalah pendukung pendidikan dan pelajaran baca tulis. Dimulai sejak Harun alRasyid, mereka berpendapat bahwa setiap anak-anak Muslim memiliki kesempatan untuk belajar dasar-dasar membaca, menulis, berhitung, ilmu pengetahuan dasar, geografi, sejarah dan sebagainya. Mereka mendirikan sekolah dasar di setiap masjid atau tempat peribadatan. Guru-guru yang pandai mengajar anak-anak orang kaya dan anak orang miskin dengan perlakuan yang sama. Sehingga sangat sulit untuk menemukan orang-orang muslim yang tidak dapat membaca atau menulis (Mehdi Nakosteen, 1995: 59).

Tulisan ini bertujuan mendeskripsikan lembaga pendidikan Islam periode klasik yang berkaitan dengan pendidikan anak pada tingkat dasar termasuk di dalamnya bentuk-bentuk lembaga pendidikan, materi yang diajarkan serta metode pengajaran yang digunakan pada lembagalembaga pendidikan tersebut. Periode klasik disini mengacu pada pembabakan sejarah menurut Harun Nasution yang menempatkan 650 $1250 \mathrm{M}$ sebagai periode kasik Islam yang dimulai dari fase ekspansi, integrasi dan puncak kemajuan pada 650-1000 Masehi hingga fase disintegrasi dari 1000 - 1250 Masehi. Dimana ciri-ciri periode ini adalah dimulainya penciptaan komunitas Islamdi tanah Arab, penaklukan Islam 
dan perubahan nilai-nilai sosial kemasyarakatan termasuk lembaga pendidikannya.

\section{Jenis-jenis Pendidikan Dasar Periode Awal Islam}

\section{Pendidikan Keluarga}

Menurut Hasan Langgulung, lebih kurang tiga tahun lamanya Rasulullah menjadikan keluarga sebagai lembaga pendidikan Islam guna mengadakan dan menyalurkan perubahan dalam masyarakat (Mahmud Yunus, 1996). Dalam sejarah tercatat bahwa rumah tangga yang dijadikan basis dan markas pendidikan Islam pertama adalah rumah (dar) Arqam bin Arqam. Arqam bin Arqam yang masuk Islam berkat dakwah yang dilakukan Abu Bakar As-Shiddiq, menyediakan rumahnya untuk dipakai Nabi Muhammad Saw sebagai tempat pembinaan orang-orang yang telah masuk Islam. Rumah Arqam ini terletak di Bukit Safa, persis depan pintu Ka'bah. Arqam, jauh sebelum Islam, sudah dikenal sebagai seorang yang aktif dalam kegiatan sosial hilful-fudul, semacam gerakan penolong bencana alam dan penyantun orang yang tidak mampu (Badri Yatin, 2002: 97).

Di sanalah Nabi mengajarkan dasar-dasar/pokok-pokok agama Islam kepada para sahabatnya untuk disampaikan ke keluarganya di rumah. Dari rumah Arqamlah pendidikan Islam menyebar ke rumahrumah para sahabat lainnya. Pendidikan anak-anak dimulai di rumahnya masing-masing. Ketika si anak mulai bisa bicara, si ayah wajib mengajarinya untuk mengucapkan kalimat tauhid: la ilaha illa Allah. Dan ketika ia berumur enam tahun ia mesti diajari untuk melaksanakan sholat wajib. Pada usia itu pulala dimulainya pendidikan formalnya (Philip K. Hitti, 2006).

Dalam pendidikan di keluarga anak mendapatkan penanaman keimanan sebagai dasar dari agama. Nabi Muhammad Saw mengajarkan bahwa keberimanan itu perlu ditanamkan dalam hati. Keimanan itu bukan di kepala, bukan berupa pengetahuan. Karena iman itu di dalam hati, maka iman tidak cukup diajarkan sebagai pengetahuan melainkan ditanamkan. Nabi mengajarkan bahwa pendidikan keimanan itu pada dasarnya dilakukan oleh orang tuanya. 
Caranya melalui peneladanan dan pembiasaan oleh orang tua (Ahmad Tafsir, 2002). Orang tua adalah orang yang menjadi anutan anaknya. Setiap anak, mula-mula mengagumi kedua orang tuanya. Semua tingkah orang tuana ditiru oleh anak itu. Karena itu, peneladanan sangat perlu. Ketika akan makan, misalnya ayahnya membaca basmalah, anak-anak menirukan itu. Takkala orang tuanya shalat, anak kecil itu diajak shalat, sekalipun mereka belum mengetahui cara dan bacaannya. Takkala puasa ramadhan, orang tuanya mengajak anak-anaknya makan sahur. Takkala idul fitri, anak-anak dibawa ke lapangan atau masjid. Takkala ayahnya datang atau bepergian selalu mengucapkan salam. Begitulah yang dilakukan Nabi Muhammad Saw dan para sahabatnya dalam mendidik anak-anak di keluarga. Hasilnya, keluarga Nabi Muhammad Saw dan keluarga para sahabatnya menjadi orang-orang yang berimat kuat.

\section{Masjid}

Masjid dalam sejarah pendidikan Islam tidak hanya berfungsi sebagai tempat ibadah tetapi juga berfungsi sebagai pusat pendidikan dan kebudayaan. Masjid dalam fungsinya sebagai pusat pendidikan dan kebudayaan memainkan peranan yang penting pada periodeperiode pertama. Sebagai lembaga pendidikan, ia merupakan pusat tempat berlakunya proses pendidikan Islam.

Sentralnya fungsi masjid sebagai lembaga pendidikan pada periode pertama ini, maka ia tidak saja digunakan sebagai tempat pendidikan orang dewasa (laki-laki), tetapi juga digunakan sebagai tempat belajar bagi kaum wanita dan anak-anak. Bagi orang dewasa, masjid berfungsi sebagai tempat belajar al-Qur'an, Hadits, fiqh, dasar-dasar agama, bahasa dan sastra Arab. Pendidikan dan pengajaran bagi kaum wanita diberikan satu kali seminggu. Mereka diajarkan al-Qur'an, hadits, dasar-dasar agama dan keterampilan menenun atau memintal. Pendidikan anak-anak juga diberikan di masjid serta suffah dekat masjid. Dalam pendidikan mereka disatukan tanpa adanya pembagian kelas. Anak-anak orang Islam yang sudah berumur enam tahun diharuskan belajar al-Qur'an, agama, bahasa 
Arab, dan berhitung dan untuk seterusnya diajarkan pula menunggang kuda, berenang dan memanah

Pada masa nabi Muhammad Saw dan khalifah Abu Bakar Shiddiq masjid masih berfungsi sebagai tempat ibadah dan pendidikan Islam tanpa ada pemisahan yang jelas antara keduanya hingga masa Amirul Mukminin, Umar ibn Khattab. Pada masanya, di samping atau di beberapa sudut masjid dibangun kuttab-kuttab, untuk tempat belajar anak-anak sehingga tidak mengganggu aktivitas ibadah masyarakat. Sejak masa inilah pengaturan pendidikan anak-anak dimulai. Hari Jum'at adalah hari libur mingguan sebagai persiapan melaksanakan shalat Jum'at. Khalifah Umar ibn Khattab mengusulkan agar para pelajar diliburkan pada waktu dzuhur hari kamis, agar mereka bersiap-siap menghadapi hari Jum'at. Usul ini kemudian menjadi tradisi hingga sekarang (Armai Arif, 2004: 41).

Pendapatnya ini tersebar ke berbagai kota dan agaknya terus meluas secara wajar tanpa diperintah atau diumumkan secara resmi, karena hal tersebut merupakan cerminan dari corak kepribadian yang khas yang disenangi serta keimanan yang kuat yang menjadikannya berwibawa. Selanjutnya lembaga pendidikan yang berpusat di masjid dalam perkembangannya mendirikan yayasan. Ada yayasan khusus yang dijalankan oleh para pengelola dengan usaha pribadi, kadangkadang sebagian mereka terpaksa mengambil upah yang sedikit untuk memenuhi kebutuhannya karena mereka disibukkan dengan kegiatan pendidikan dan meninggalkan upaya pencarian rezeki (Armai Arif, 2004).

\section{Kuttab}

Maktab atau kuttab sesungguhnya merupakan sebuah tempat untuk belajar membaca maupun menulis, yang terletak di rumah guru dimana para murid berkumpul untuk menerima pelajaran (Mehdi Nakosteen, 1995). Llembaga pendidikan Kuttab telah ada sejak masa Arab pra-Islam. Hal ini tentu saja terkait dengan kegiatan pendidikan yang berlangsung saat itu. Dengan merujuk kitab 'Uyun al-Akhbar karya Ibn Qutaibdah, tulisan M. Hamidullah, "Educational System in 
the Time of the Prophet", dalam Islamic Culture, yang dikutip Armai Arif menguraikan bahwa Zilmah, salah seorang perempuan anggota suku Hudhail, pada masa kecilnya memasuki sekolah dan biasa bermain-main dengan tinta yang dipakai untuk menulis. Selain, itu Ghailan ibn Salmah dari suku Taif juga terkenal sering mengadakan pertemuan mingguan di mana para penyair membacakan syairsyairnya dan mendiskusikan dan mengkritisi karya-karya mereka.

Di kota Makkah, kegiatan pendidikan juga berlangsung dengan standar yang lebih tinggi. Tujuh Mu'allaqat digantung di Ka'bah sebagai bukti keunggulan karya-karya tersebut. Waraqah Ibn Naufal adalah seorang penduduk Makkah yang menerjemahkan perjanjian Lama dan Baru ke dalam bahasa Arab. Menurut Hamidullah, kegiatan pendidikan juga dilakukan oleh para penganut Kristen dan Yahudi, dimana terdapat diwan (kumpulan syair) karya Samaw 'Adiya. Orang-orang Yahudi Madinah telah mendirikan Bait al-Midras yang bertahan sampai masa Islam dan menjadi pusat kegiatan pendidikan dan agama. Selanjutnya, penggunaan kosa kata yang berkaitan dengan alat-alat tulis menulis atau giatan tulis menulis di dalam al-Qur'an seperti Qalam, nun, raqq, marqum, mastur, maktub dan sebagainya, menjadi bukti lain bahwa kegiatan pendidikan sudah berlangsung pada masa Arab pra-Islam (Armai Arif, 2004: 47).

Penjelasan Hamidullah tersebut belum menunjukkan apakah kegiatan pendidikan tersebut bersifat massal atau hanya diikuti oleh orang-orang tertentu. Dalam hal ini Ahmad Syalabi, dengan merujuk pada karya Al-Baladuri, Futuh al-Buldan menjelaskan bahwa Sufyan bin Umayya dan Abu Qais bin Abd Manaf adalah orang Arab asli pertama yang belajar membaca dan menulis. Guru mereka adalah seorang Nasrani bernama Bishr 'Abd al-Malik yang telah belajar ilmu ini di Hira. Dan orang Arab pertama yang menjadi guru adalah Wadi al-Qurra yang hidup di sana dan memulai mengajarkan dan membaca dan menulis kepada penduduk Arab. Sehingga, pada saat datangnya Islam hanya ada 17 orang Quraisy. Sejarah pendidikan Islam juga mencatat ada dua jenis kuttab pada zaman awal Islam. Kuttab jenis pertama dalah kutttab yang lahir masa pra-Islam tapi terus berlanjut 
setelah masa Islam. Kuttab ini mengajarkan tulis baca dan teks dasar puisi-puisi Arab, dan dengan sebagian besar gurunya orang-orang non Muslim.

Kuttab jenis kedua adalah kuttab yang berfungsi sebagai tempat pengajaran Al-Qur'an dan prinsip-prinsip Islam lainnya. Banyak di kalangan ilmuwan seperti halnya Philip K Hitti, Ahmad Amin dan Ignaz Goldzihr yang terjebak dengan menyamakan kedua jenis kuttab itu, sehingga akibatnya baik pelajaran baca tulis maupun pelajaran alQur'an dan pelajaran dasar-dasar agama lainnya diajarkan pada kuttab yang sama dan kemungkinan guru-guru non muslim mengajar baca tulis al-Qur'an kepada anak-anak Muslim. Menurut Ahmad Syalabi, kedua jenis kuttab ini terpisah. Kuttab jenis kedua tidak ditemui pada masa paling awal ketika kuttab jenis pertama sudah berkembang. Pengajaran al-Qur'an pada kuttab jenis kedua ini baru berkembang pada masa Umayyah setelah jumlah qurra dan huffadz telah banyak dan al-Qur'an telah banyak digandakan. Pada masa-masa sebelumnya pengajaran al-Qur'an berlangsung dalam halqah di masjid-masjid atau rumah-rumah secara informal (Armai Arif, 2004: 50).

Kenyataan ini menunjukkan bahwa sejak Islam lahir, sudah terasa pentingnya baca tulis. Walaupun anak-anak muslim tidak pernah belajar al-Qur'an kepada guru-guru non Muslim, tetapi tidak demikian halnya dengan belajar baca tulis. Anak-anak muslim tidak mengapa belajar baca tulis kepada guru yang bukan orang muslim. Dengan demikian, syarat muslim untuk menjadi guru pada masa lalu tidak sepenuhnya benar dalam kondisi-kondisi tertentu. Rasul juga mempunyai perhatian terhadap pentingnya baca tulis waktu itu. Hal ini dibuktikan dua tindakan Rasul dalam hal ini, pertama, Rasul membebaskan tawanan perang Badr, setelah mereka mengajarkan tulis baca kepada sejumlah anak-anak Muslim. Kedua, Rasul memerintahkan Al-Hakam bin Sa'id untuk mengajar pada sebuah kuttab di Madinah.

Peserta didik di kuttab jenis pertama belajar baca tulis dengan teks dasar puisi-puisi Arab. Hal ini menunjukkan bahwa sebelum adanya al-Qur'an, puisi-puisi Arab sangat penting sebab biasanya 
berisi ungkapan bahasa yang halus dan mempunyai nilai etika yang tinggi. Rasul pun membanggakan dirinya karena pernah di asuh oleh Halimah al-Sa'diyah di suatu tempat yang bahasanya masih murni dan halus. Rasulullah berkata tentang masa silamnya sebagai berikut: "Aku orang terpisah di antara kamu, dan aku seorang Quraisy yang dibesarkan di dusun keluarga Banu Sa'ad bin Bakr”. Pada masamasa selanjutnya setelah kuttab jenis kedua, pelajaran terfokus kepada Al-Qur'an. Al-Qur'an dijadikan buku muthala'ah untuk belajar pelajaran membaca, dan kemudian memilih ayat-ayat alQur'an untuk dijadikan bahan pelajaran menulis. Di samping belajar membaca dan menulis, mereka mulai belajar kaidah-kaidah bahasa Arab, kisah-kisah Nabi khususnya hadits-hadits Nabi. Di sini mulai terlihat pelajaran Al-Qur'an sudah mulai menggeser peran syair Arab, dan materi pelajaran lain lahir karena mendukung pelajaran al-Qur'an

\section{Sekolah Istana}

Selain pada kuttab dan masjid, Pendidikan tingkat dasar juga berlangsung di sekolah khusus di istana atau di kediaman keluarga bangsawan. Para khalifah dan pembesar-pembesar kerajaan mengadakan pendidikan dan pengajaran di Istana dengan mengundang guru-guru yang ahli untuk mendidik anak-anaknya, supaya dapat melaksanakan tugas yang akan dipikulnya kelak di kemudian hari. Pengajaran di sekolah istana bukan saja pengajaran tingkat rendah, melainkan terus ke tingkat pengajaran tinggi sebagaimana di halaqah masjid dan madrasah (Mahmud Yunus, 1990: 81). Isi pengajaran pada sekolah istana sama dengan pada kuttab pada umumnya. Rencana pengajarannya, bukan diatur oleh gurunya saja, melainkan turut serta orang tua murid, supaya sesuai dengan kebutuhan anaknya. Kelompok elit dan keluarga kaya menekankan (keterampilan) membaca, menulis, pelajaran agama, dan puisi; tetapi juga keterampilan menunggang kuda, berenang dan aritmatika (Michael Stanton, 1994: 20).

Guru yang sekolah istana tidak dinamai guru kanak-kanak atau guru kuttab, melainkan dinamai muaddib (yang memberi adab). Guru 
yang mengajar di sekolah istana atau rumah keluarga hartawan memperoleh gaji yang lebih baik dari guru di kuttab ataupun madrasah. Mereka memperoleh hak istimewa dari khalifah atau pembesar istana, memperoleh penginapan, makanan dan fasilitas lainnya. Tergantung pada kekayaan satu keluarga, seorang guru mungkin dihadiahi kuda, perabotan, rumah, pembantu, dan kesempatan untuk bepergian dan bergaul dengan kelompok elit masyarakat. Shalaby mengutip gaji rata-rata sekitar 1.000 dirham perbulan (sekitar U.S. 240), walaupun banyak yang menerima lebih besar dari itu (Michael Stanton, 1994: 22). Berbeda dengan pendidikan dasar yang mengundang para guru ke istana yang dilakukan pada masa kerajaan Abbasiyah, pada masa kekhalifahan bani Fatimiyah, mereka tidak hanya mendatangkan guru untuk mengajar anak-anak ke istana, melainkan juga mendirikan madrasahmadrasah khusus di istana mereka tempat belajar bagi anak-anak khalifah dan pembesar-pembesar lainnya. Di sana guru-guru mendidik anak-anak mereka menurut rencana yang sesuai dengan tugas mereka kelak kemudian hari (Mahmud Yunus, 1990: 84).

\section{Materi dan Metode Pengajaran Pada Pendidikan Dasar}

Salah seorang filsafat Islam, Ibnu Sina, mengatakan bahwa seorang anak yang berada dalam usia 3-5 tahun harus diajarkan ilmuilmu yang sejalan dengan pertumbuhan panca indera, gerak badan,budi pekerti, dan perasaan. Pelajaran gerak badan atau olahraga tersebut diarahkan untuk membina pertumbuhan fisiknya, sedangkan pendidikan budi pekerti diarahkan untuk membiasakan agar anak memiliki sopan santun dalam pergaulan hidupnya sehari-hari. Sedangkan untuk anak usia sekolah dasar (6-14 tahun), menurut Ibnu Sina, maka materi yang diajarkan adalah (1) pelajaran membaca dan menghafal Al-Qur'an, (2) pelajaran agama, (3) pelajaran bahasa, (4) pelajaran syair, dan (5) pelajaran agama/fiqh (Ahmad Ridlo, 2017: 69).

Pada masa khulafaurrasyidin dan Bani Umayyah telah ada pembagian kurikulum pendidikan berdasarkan tingkat pendidikannya. Tingkat pertama ialah materi pengajaran di kuttab tempat anak-anak 
belajar menulis dan membaca/menghafal Al-Qur'an serta belajar pokokpokok agama Islam. Setelah al-Qur'an mereka meneruskan pelajaran ke masjid. Isi pelajaran di masjid terdiri dari tingkat menengah dan tingkat tinggi. Pada tingkat menengah, gurunya belumlah ulama besar, sedangkan pada tingkat tinggi, gurunya ulama yang mendalam ilmunya dan masyhur kealiman dan kesalehannya. Pada tingkat dasar, pelajaran umumnya diberikan guru kepada murid-murid seorang demi seorang. Ilmu-ilmu yang diajarkan pada mula-mulanya adalah dalam keadaan sederhana seperti (a) belajar membaca dan menulis; (b) membaca alQur'an dan menghafalnya; (3) belajar pokok-pokok agama Islam, seperti cara berwudhu, sembahyang, puasa dan sebagainya (Mahmud Yunus, 1990: 40).

Pada masa khalifah Umar bin Khattab beliau kemudian menginstruksikan kepada penduduk-penduduk kota, supaya pada pendidikan dasar juga diajarkan kepada anak-anak (a) berenang; (b) mengendarai kuda; (c) memanah; (d) membaca dan menghafal syairsyair mudah dan peribahasa. Dengan demikian mulai masuk dalam pengajaran tingkat dasar materi olah raga gerak badan dan membaca syair-syair mudah, serta peribahasa. Sedangkan sebelum itu hanya fokus ke al-Qur'an saja (Mahmud Yunus, 1990). Ketika mengunjungi Damaskus pada $1184 \mathrm{M}$, Ibn al-Jubayr mendapati bahwa anak-anak mendapatkan kesempatan menulis dengan rujukan dari puisi-puisi Arab tempo dulu, bukan dari Al-Qur'an karena diyakini bahwa tindakan menghapus lafadz Allah berarti menghina dan merendahkan-Nya. Bersamaan dengan pelajaran baca tulis, anak-anak juga mempelajari tata bahasa Arab, kisah-kisah para nabi, khususnya hadits-hadits Nabi, dasardasar aritmatika, dan mereka juga mempelajari puisi, dengan syarat tidak bersifat erotis (Philip K. Hitti, 2006).

Pada perkembangan lebih lanjut, pelajaran di kuttab semakin berkembang, Muhammad Athiyah al-Abrasy mengemukakan sejumlah materi pelajaran kuttab yang meliputi: membaca al-Qur'an, menulis, pokok-pokok agama, bahasa, ilmu hitung dan tata bahasa (Muhammad: 73). Tiap-tiap kuttab tidak menunjukkan keseragaman dalam memberikan materi pelajaran. Materi pelajaran yang diberikan di kuttab- 
kuttab bervariasi, tergantung pada kebutuhan daerah tertentu dan tentu saja tergantung pada kemampuan para ulamanya. Ibn Khaldun (w.808/1406 M) mencatat perbedaan praktik pendidikan kuttab pada masanya, sebagai berikut. Pertama, umat Islam al-Maghrib (Maroko) sangat menekankan pengajaran al-Qur'an. Anak-anak di daerah ini tidak akan belajar sesuatu yang lain sebelum menguasai al-Qur'an secara baik. Pendekatan mereka adalah pendekatan ontografi (mengenali satu bentuk kata dalam hubungannya dengan bunyi bacaan). Itulah sebabnya, menurut Ibn Khaldun, Muslim Maroko dapat menghafal al-Qur'an lebih baik dibanding Muslim dari daerah lain. Kedua, Muslim Spanyol (alAndalus) mengutamakan menulis dan membaca. Al-Qur'an tidak diutamakan dibandingkan dengan puisi dan bahasa Arab. Penekanan pada pelajaran menulis melahirkan ahli-ahli kaligrafi yang dapat membaca dan menyalin al-Qur'an tanpa harus menghafalnya. Ketiga, daerah Ifraqiyah (Afrika Utara: Tunisia, al-Jazair dan Libya). Di sini pendidikan kuttab mengutamakan al-Qur'an dengan tekanan khusus pada variasi bacaan (qira'at); lalu diikuti dengan seni kaligrafi dan hadits. Daerah keempat yang dibicarakan oleh Ibn Khaldun adalah daerah Timur (al-Masyriq:Timur Tengah, Iran, Asiah Tengah dan Semenanjung India) yang menurut pengakuannya -tidak ia ketahui secara jelas dibandingkan tiga daerah yang pertama. Secara umum daerah Timur ini menganut kurikulum campuran, dengan al-Qur'an sebagai inti; tetapi tidak memadukannya dengan keterampilan kaligrafi, sehingga tulisan tangan anak-anak Muslim dari Timur tidak begitu baik (Armai Arif, 2004: 51).

Pada pendidikan dasar di istana, materi yang diajarkan adalah materi-materi keagamaan, karya sastra yang sopan, kecakapan menulis dll. Gambaran pendidikan ideal yang diinginkan di pendidikan dasar di Istana bisa dilihat dari perintah Harun Al-Rasyid kepada guru pribadi anaknya, Al-Amin:

"Aku serahkan kepadamu anakku, buah sulbiku, aku memberikmu kekuasaan atasnya dan membuatnya patuh kepadamu. Karenanya kamu harus membuktikan diri sebagai orang yang layak menerima kedudukan ini. Ajarlah dia Al-Qur'an, sejarah, puisi, hadits, dan penghargaan terhadap kefasihan bahasa. Cegah dia dari tertawa, kecuali pada kesempatan yang sesuai. Biasakanlah dia untuk 
menghormati para pemuka Bani Hasyim dan untuk memberikan tempat yang sesuai kepada pemimpin-pemimpin militer bila mereka menghadiri majlisnya. Jangan biarkan waktu berlalu tanpa pelajaran yang bermanfaat baginya, tetapi jangan buat ia sedih. Jangan terlalu baik padanya, sebab dengan begitu ia akan menjadi malas. Didiklah ia dengan lemah lembut, tetapi kalau itu cukup, engkau boleh memperlakukannya dengan keras (Michael Stanton, 1994: 20).

Murid-murid terbaik di sekolah dasar biasanya akan mendapat kehormatan untuk mengikuti parade, mereka menaiki seekor unta, menyusuri jalan-jalan di kota dan orang-orang akan melemparkan buah badam (almond) kepada mereka. Kesemarakan serupa bisa dilihat ketika ada murid sekolah dasar yang mampu menghafal seluruh ayat-ayat alQur'an. Pada beberapa kesempatan tertentu, murid-murid akan mendapatkan hadiah berupa liburan sekolah jika mereka berhasil menghafal salahsatu juz Al-qur'an (Philip K. Hitti, 2006: 513). Anakanak perempuan perempuan mendapat kesempatan yang sama dengan anak laki-laki untuk mengetahui ajaran-ajaran agama pada tingkatan yang lebih rendah sesuai dengan kemampuan pikiran untuk menerimanya. Meskipun demikian, penguasa atau masyarakat tidak memiliki keinginan untuk membimbing mereka agar bisa menempuh jalur pendidikan yang lebih tinggi. Alasan utamanya, bisa jadi, karena menganggap dunia pendidikan bukanlah kebutuhan utama yang diperlukan perempuan.

Adapun metode yang digunakan pada pendidikan dasar adalah membaca dan menghafal al-Qur'an dan puisi-puisi kuno. Pada awalnya, siswa menuliskan pelajaran mereka dengan jari di atas pasir. Kemudian lembaran yang terbuat dari tanah liat menjadi popular; dan dengan masuknya kertas dari Timur pada abad ke delapan, pelajar dapat menyimpan catatan mereka dalam bentuk manuskrip. Oleh itu latar belakang tradisi oral yang panjang, maka pendidikan mendorong siswa untuk menghafal al-Qur'an dan sebanyak mungkin materi pelajaran lainnya(Michael Stanton, 1994: 20). Hal ini sesuai dengan prinsip pada saat itu yang menyatakan "ilmu itu dalam dada bukan dalam tulisan, ilmu itu bukan yang disimpan dalam lemari, melainkan yang di simpan dalam dada". Oleh karena itu, murid harus menghafal semua materi 
pelajaran yang dipelajarinya, sehingga jika tulisannya hilang atau terkoyak, ia dapat membacakannya dengan tidak berubah sedikitpun juga dari aslinya, terutama kitab hadits. Sistem ini masih dituruti hingga sekarang di beberapa pendidikan Islam.

\section{SIMPULAN}

Lembaga pendidikan dasar dalam sejarah Islam klasik baik dalam bentuk informal dan formal merupakan adaptasi dari lembaga pendidikan keluarga dan kuttab pada masa pra Islam. Lembaga ini kemudian mengalami proses islamisasi pada aspek pengajar, metode dan isi kurikulumnya yang disesuaikan dengan nilai-nilai keislaman. Kesemuanya ini dilakukan dalam rangka anak-anaknya agar mampu menerima warisan Islam dan bertanggung jawab untuk mengemban tugas pengembangan dan dakwahnya, Keberadaan lembaga keluarga, masjid, kuttab, sekolah istana sebagai lembaga pendidikan dasar dalam periode klasik menunjukkan bahwa masyarakat muslim telah mengembangkan sistem pendidikan yang berjenjang sesuai dengan perkembangan jiwa anak yang disesuaikan dengan materi yang ada. Pola pembelajaran dengan menggunakan sistem hafalan sebagai metode utama yang ada pada masa itu tidak lepas dari tradisi oral dan paradigma yang ada masa itu bahwa pendidikan merupakan proses pewarisan nilainilai luhur ke generasi muda. Meskipun demikian, pada kenyataannya metode diskusi antara siswa dengan pengajar sudah lazim ditemukan dalam pendidikan Islam pada periode klasik.

\section{DAFTAR PUSTAKA}

Ahmad Ridlo SU. 2017. Ibnu Sina: Ilmuwan, Pujangga, Filsuf Besar Dunia. Yogyakarta: Sociality.

Ahmad Tafsir (ed.,). 2002. Pendidikan Agama Dalam Keluarga. Bandung: Remaja Rosdakarya.

Armai Arief (ed.,). 2004. Sejarah Pertumbuhan dan Perkembangan Lembaga Pendidikan Islam Klasik. Bandung: Angkasa. 
Badri Yatim. 2002. "Muhammad SAW di Mekah' dalam Taufik Abdullah (ed.,), Ensiklopedi Tematis Dunia Islam: Akar dan Awal, Jild I. Jakarta: PT. Ichtiar baru Van Hoeve.

Charles Michael Stanton. 1994. Pendidikan Tinggi Dalam Islam: Sejarah dan Peranannya Dalam Kemajuan Ilmu Pengetahuan, terjm. H. Afandi Hasan Asari. Jakarta: Logos Publishing House.

Mahmud Yunus. 1990. Sejarah Pendidikan Islam dari Zaman Nabi Saw, Khalifah-Khalifah Rasyidin, Bani Umayya dan Abbasiyah Sampai Zaman Mamluks dan Usmaniyah Turki, (Jakarta: PT. Hidakarya Agung.

Mahmud Yunus. 1966. Sejarah Pendidikan Islam. Jakarta: Mutiara.

Mehdi Nakosteen. 1995. Kontribusi Islam Atas Dunia Intelektual Barat: Deskripsi Analisis Abad Keemasan Islam, terjm. Joko S. Kahar dan Supriyanto Abdullah. Surabaya: Risalah Gusti.

Muhammad 'Athiyyat al-Abrasyi, Al-Tarbiyah al-Islamiyah. tt: Dar' alFikr, ttg.

Philip K. Hitti. 2006. History of the Arabs: From the Earliest Times to the Present, terjm. R.Cecep Lukman Yassin dkk,, (Jakarta: PT Serambi Ilmu Semesta.

Syafiq A. Mughni. 2002. "Masyarakat Arab Pra Islam" dalam Taufik Abdullah (ed.,), Ensiklopedi Tematis Dunia Islam: Akar dan Awal, Jild I, (Jakarta: PT. Ichtiar baru Van Hoeve. 